\title{
NILAI EKONOMI PEMANFAATAN FLORA DI TAMAN NASIONAL BALURAN
}

\author{
Economic Value of Flora Utilization in Baluran National Park
}

Joko Mulyo Ichtiarso

Staf Taman Nasional Baluran, Jawa Timur

Diterima 1 Agustus 2020/Disetujui 1 Oktober 2020

\begin{abstract}
One of ecosystem services that is used by buffer community village flora that is component ecosystem at Baluran National Park (BNP). Form of flora that is used by community are fruit, under story, tubers, and so on. This motivates to calculate economic value of flora as component ecosystem. The object of study is to know how much economic value of ecosystem services especially from fauna in BNP which has been utilized by community buffer village and dependence on BNP. The method of study by quantitative and qualitative approaches. Data collected are typological conditions of BNP community buffer village, human resources who used the services of BNP ecosystem services, identity of community who used ecosystem services, types of ecosystem services used by community, harvest season, location of ecosystem services, community income that uses ecosystem and dependence on BNP ecosystem services. The result of study are economic value of flora that is component of ecosystem that have been utilized by community buffer village are candlenut (Rp. 1,306,694,400), tamarind (Rp. 1,292,085,000), acacia (Rp. 3,951,415,200), gadung (Rp. 924,160,800), firewood (Rp. 1,409,100,000), grass (Rp. 5,154,600,000), and ramban (Rp. 72,240,000). Total economic is $R p$. 14,110,295,400,- per year.
\end{abstract}

Keywords: Flora, Ecosystem services, Baluran National Park

\section{PENDAHULUAN}

Tujuan pengelolaan Taman Nasional Baluran (TNB) tidak hanya untuk menjaga kelestarian sumber daya alama hayati di dalamnya, namun harus dapat memberikan manfaat juga secara ekonomi bagi masyarakat sekitar. Sepertinya halnya diungkapkan oleh Soekmadi (2003) menyatakan bahwa kawasan konservasi harus dapat memberikan manfaat yang nyata terhadap masyarakat sekitarnya. Pemanfatan di taman nasional yang dapat dilakukan berdasarkan Peraturan Pemerintah RI No. 28 Tahun 2011 tentang Pengelolaan Kawasan Suaka Alam dan Kawasan Pelestarian Alam dalam pasal 1, yaitu pemanfaatan jenis tumbuhan dan 
satwa liar serta kondisi lingkungannya dengan tetap memerhatikan kelangsungan potensi, daya dukung dan keanekaragaman jenis tumbuhan dan satwa liar.

Faktanya sampai saat ini masih banyak masyarakat di sekitar taman nasional termasuk ke dalam kelompok masyarakat yang memiliki perekonomian rendah, bahkan menurut Ekayani et.al. (2014) kondisi tersebut dapat menyebabkan adanya konflik kepentingan antara pihak pengelola dengan masyarakat. Hal ini terjadi juga pada TNB yang dikelilingi oleh 5 desa yang berbatasan dan/ atau berada di dalam kawasan. Kondisi tersebut membuat masyarakat memiliki ketergantungan secara ekonomi terhadap TNB, salah satunya dengan memanfaatkan flora yang berada baik di dalam maupun di luar kawasan.

TNB merupakan salah yang memiliki beragam jasa ekosistem berupa hasil hutan bukan kayu (HHBK) berupa flora, fauna, wisata, dan siklus nutrient (ketersediaan karbon). Suhendang (2013) menyatakan bahwa manfaat ekosistem hutan merupakan segala bentuk sumbangan dari keluaran yang dihasilkan akibat proses biologis, fisika, kimiawi, dan sosial budaya di dalam hutan yang berguna bagi kehidupan manusia dan lingkungannya. Dalam kenyataannya belum semua jasa ekositem dimanfaatkan oleh masyarakat di TNB.

HHBK di TNB hasil survey BTNB (2014) terdapat sebanyak 10 jenis yang telah dimanfaatkan oleh masyarakat desa penyangga yang tersebar hampir di semua zona kawasan. Hal ini dikarenakan masyarakat seakan tidak mempedulikan informasi dan peraturan yang ada di TNB terkait pemanfaatan jasa ekosistem ini. Pengambilan HHBK yang seharusnya hanya di zona pemanfaatan dan tradisional atau pemanfaatan khusus saja, pada kenyataanya sudah terlampau masuk ke semua zona bahkan di zona inti.

Data hasil survey tersebut diharapkan dapat meningkatkan kesadaran masyarakat akan pentingnya kawasan konservasi dan dapat memperkecil kerusakan atau degradasi hutan di TNB. Selain itu, masyarakat juga diharapkan akan memiliki keinginan untuk terlibat dalam upaya-upaya perlindungan dan pelestarian kawasan TNB serta lebih bijaksana dalam melakukan pemanfaatan sumberdaya alam, khusunya flora di TNB. Tujuan dari penelitian ini adalah mengidentifikasi flora yang dimanfaatkan oleh masyarakat desa penyangga, menghitung nilai ekonomi flora yang dimanfaatkan, dan menghitung tingkat ketergantungan ekonomi masyarakat terhadap flora tersebut.

\section{METODE PENELITIAN}

Penelitian dilakukan di semua pintu masuk kawasan TNB yang jumlahnya 12 pintu yang tersebar di 5 desa penyangga TNB, yaitu Desa Sumberanyar, Desa 
Sumberwaru, Desa Wonorejo, Desa Watukebo, dan Desa Bajulmati (Gambar 1). Lokasi penelitian meliputi seluruh zona taman nasional, yaitu zona inti, zona rimba, zona khusus, zona rehabilitasi, zona pemanfaatan, zona tradisional, dan zona perlindungan bahari. Penelitian dilakukan pada bulan Januari hingga Februari 2019.

Data yang dikumpulkan meliputi: 1) karakteristik responden masyarakat pemanfaat jasa ekosistem; 2) jenis dan jasa ekosistem flora (HHBK flora) yang dimanfaatkan oleh masyarakat, meliputi tumbuhan bawah, daun, buah, biji, dan ranting; 3) musim pengambilan atau pemungutan; 4) lokasi pemungutan; 5) pendapatan masyarakat pemanfaat jasa ekosistem; 6) tingkat ketergantungan masyarakat terhadap jasa ekosistem TNB; 7) sumber daya finansial (mata pencaharian, pendapatan dan pengeluaran masyarakat). Data dikumpulkan melalui studi dokumen dan wawancara mendalam (in depth interview) modifikasi dari Sugiyono (2009). Pemberian kuisioner dan wawancara mendalam dilakukan kepada masing-masing pemanfaat jasa ekosistem dan 5 kepala desa penyangga. Pemilihan responden dan informan dilakukan secara purposive sampling.

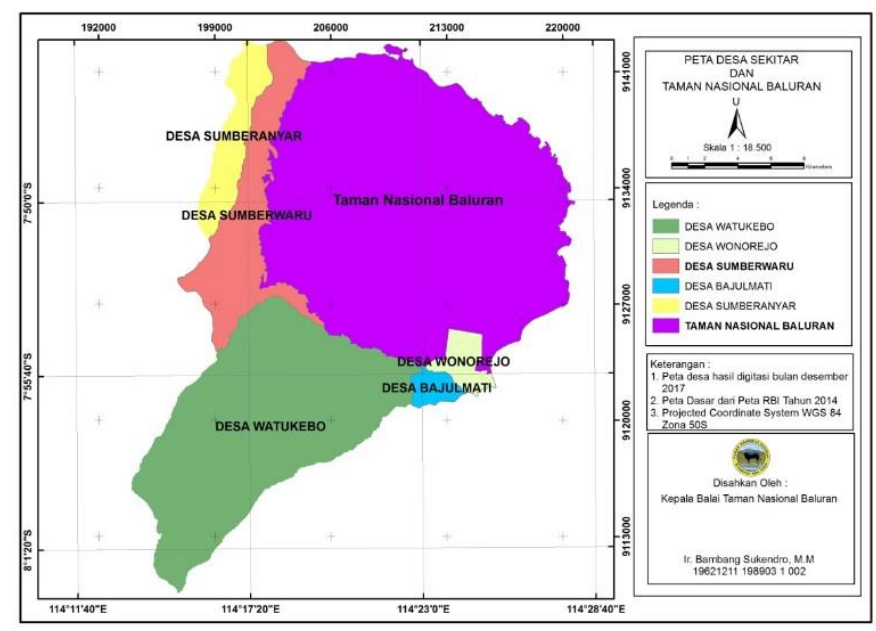

Gambar 1. Lokasi penelitian

Nilai ekonomi jasa ekosistem HHBK berupa flora dihitung dengan pendekatan harga pasar (market based approach) dengan rumus sebagai berikut:

Keterangan :

$$
\mathrm{Bv}=\mathrm{P} \times \mathrm{V} \times \mathrm{I} \times \mathrm{N}
$$

$\mathrm{Bv}=$ nilai manfaat jasa ekosistem yang dimanfaatkan (Rp/tahun)

$\mathrm{P}=$ rata-rata harga pasar

$\mathrm{V}=$ volume rata-rata jasa ekosistem per satu kali pengambilan

$\mathrm{I}=$ intensitas pengambilan SDAH dalam satu tahun

$\mathrm{N}=$ jumlah pemanfaat/pengambil SDAH. 


\section{HASIL DAN PEMBAHASAN}

\section{Karakteristik Responden}

Responden yang memanfaatkan jasa ekosistem TNB didominasi oleh responden dengan kelas umur yang produktif (umur 25-55 tahun), yaitu sekitar $82 \%$, dan yang paling rendah berada di kelas umur 10-25 tahun, yaitu sebanyak 5\%. Hal ini menunjukkan bahwa sumber daya di dalam kawasan TNB sangat dibutuhkan untuk memenuhi kebutuhan hidup keluarganya, sehingga interaksi dan pemanfaatan flora juga akan tinggi untuk memenuhi kebutuhan ekonominya.

Tingkat pendidikan responden menunjukkan bahwa sebagian besar berpendidikan rendah yaitu tingkat sekolah dasar (SD) sebanyak 35 orang dan hanya sedikit yang berpendidikan menengah atau tinggi yaitu 4 orang. Banyak faktor yang menyebabkan masyarakat atau responden berpendidikan rendah, diantaranya: keterbatasan perekonomian keluarga, minimnya informasi tentang sekolah yang lebih baik, dan kurangnya kesadaran orang tua dan pribadi masingmasing untuk melanjutkan ke jenjang pendidikan yang lebih tinggi. Kondisi ini dapat membuat masyarakat sulit untuk mencari pekerjaan seperti halnya Nugroho et al. (2008) menyatakan bahwa pendidikan yang rendah menyebabkan masyarakat memiliki keterampilan yang kurang dan lebih lanjut Munanura et al. (2014) menambahkan bahwa pendidikan dan kesehatan akan mendorong ketergantungan masyarakat terhadap hutan.

Jenis kelamin responden adalah laki-laki sebanyak 55 orang $(91,67 \%)$ dan perempuan 5 orang $(8,33 \%)$. Hal ini menunjukkan bahwa masyarakat pemanfaat jasa ekosistem TNB yang berupa HHBK nya bukan hanya laki-laki, tetapi juga perempuan. Ibu rumah tangga yang tidak mempunyai mata pencaharian tetap untuk memenuhi kebutuhan keluarganya biasa masuk ke dalam hutan untuk memungut HHBK dan menjualnya kepada pengepul untuk mendapatkan uang. Jika kondisi ini terus dibiarkan, dikhawatirkan akan berpengaruh terhadap sumber daya alam di dalam kawasan TNB akan tereksploaitasi terus menerus dan dikhawatirkan tidak dapat berkelanjutan. Oleh karena itu diperlukan suatu aturan dan pemahaman kepada masyarakat agar memanfaatkan sumber daya secara bijaksana dan berkelanjutan.

\section{Nilai Ekonomi Jasa Ekosistem Flora TNB}

Terdapat 7 jenis flora yang dimanfaatkan oleh masyarakat desa sekitar TNB, yaitu kemiri (Aleurites moluccanus), asam (Tamarindus indica), akasia (Acacia nilotica.), gadung (Dioscorea hispida), kayu bakar, rumput, dan ramban. Masyarakat pemungut HHBK ketika musim panen telah datang, secara 
berkelompok maupun perorangan akan masuk ke dalam kawasan hutan TNB dan memungut HHBK flora dengan menggunakan berbagai cara pengambilannya. Masyarakat desa penyangga TNB biasa memungut HHBK dari dalam kawasan TNB sejak tahun 1960-an. HHBK yang lain waktu pemungutannya menyesuaikan dengan kalender musim berbunga atau berbuah (Tabel 2). Berdasarkan Tabel 2 flora yang dapat dipanen sepanjang tahun adalah ramba, kayu bakar, dan rumput.

Tabel 2. Waktu pemungutan HHBK di TNB oleh masyarakat

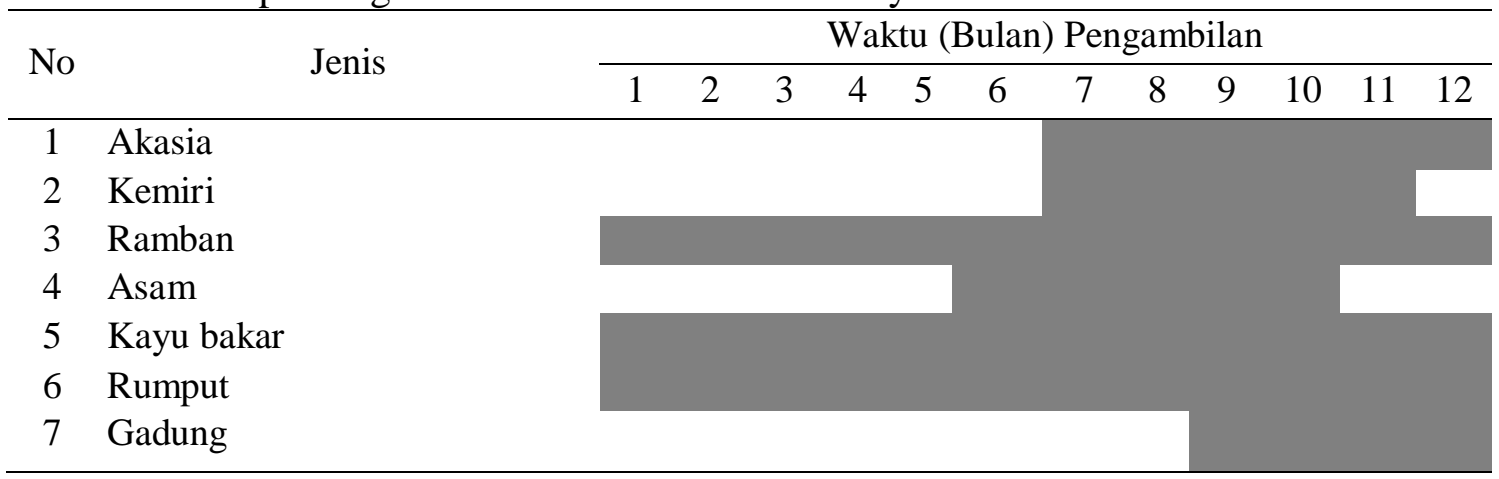

Sumber : data penelitian 2018

Sumber daya flora yang diambil kemudian dijual dengan harga tertentu yang telah ditetapkan oleh pengepul. Penetapan harga tergantung pada kondisi sumber daya, harga pasar serta permintaan terhadap sumber daya tersebut. Masyarakat juga selain untuk dijual juga untuk keperluan lainnya, seperti rumput yang diambil untuk memenuhi kebutuhan pakan ternak. Nilai ekonomi dari tiap jenis sumber daya berbeda-beda, hal ini ditentukan oleh faktor harga rata-rata sumber daya, intensitas pengambilan, rata-rata volume pengambilan dan jumlah pemungut/pemanfaat. Secara lengkap nilai ekonomi SDAH di TNB dapat dilihat pada Tabel 3.

Tabel 3. Nilai ekonomi Flora di TNB

\begin{tabular}{clcc}
\hline No & \multicolumn{1}{c}{ Jenis Flora } & Nilai manfaat (Rp/Tahun) & Persentase $(\%)$ \\
\hline 1 & Kemiri & 1.306 .694 .400 & 9,3 \\
2 & Asam & 1.292 .085 .000 & 9,2 \\
3 & Akasia & 3.951 .415 .200 & 28 \\
4 & Gadung & 924.160 .800 & 6,5 \\
5 & Kayu Bakar & 1.409 .100 .000 & 10 \\
6 & Rumput & 5.154 .600 .000 & 36,5 \\
7 & Ramban & 72.240 .000 & 0,5 \\
Total Nilai Ekonomi & $\mathbf{1 4 . 1 1 0 . 2 9 5 . 4 0 0}$ & $\mathbf{1 0 0}$ \\
\hline
\end{tabular}

Tabel 3 diketahui bahwa setiap sumber daya memberikan nilai ekonomi yang berbeda terhadap masyarakat. Sumberdaya yang memberikan kontribusi nilai ekonomi terbesar bagi masyarat adalah rumput mencapai 36,5\%. Rumput menjadi 
sumber daya dengan nilai manfaat terbesar karena dimanfaatkan dan dipanen sepanjang tahun. Sementara itu, ramban memiliki nilai kontribusi ekonomi terkecil (sebesar 0,5\%), hal ini karena memungut rambanan dari TNB hampir sebagian besar dimanfaatkan untuk pakan ternak-nya sendiri bukan untuk diperjual-belikan dan tidak semua jenis pohon dapat diambil rambanannya karena tidak semua disukai hewan ternak.

\section{Bagian Pemanfaatan Flora}

Akasia yang dimanfaatkan oleh masyarakat berupa biji (Gambar 1). Pemungutannya menggunakan galah dan jarring. Galah digunakan untuk menjangkau buah akasia yang berada di atas pohon, sedangkan jarring digunakan untuk menampung buah Akasia yang berjatuhan. Kemudian dari buah akasia tersebut diambil biji-nya dan dijemur hingga kering. Harga jual biji akasia dari pemungut kepada pengepul berkisar Rp. 3.750,-/kg. Pengepul akan menjual biji Akasia tersebut ke pasar atau pembeli dari berbagai daerah di luar Kabupaten Situbondo. Jangkauan pemasaran biji Akasia berdasarkan informasi langsung dari pengepul adalah Semarang, Madiun, Jombang, Probolinggo, dan bahkan ada permintaan dari luar jawa yaitu dari Pulau Bali dan Nusa Tenggara Barat. Sejauh ini dampak dari pemanfaatan biji Akasia di TNB belum tampak jelas. Hal ini dapat dilihat dari kerusakan pohon Akasia yang sangat minim dijumpai di lapangan (TN Baluran 2014). Artinya, aktifitas pemanfaatan biji Akasia oleh masyarakat masih bisa dipertahankan dengan mekanisme pengelolaan pemanfaatan yang lebih baik.

Kemiri yang dimanfaatkan adalah biji (Gambar 1). Hasil penelitian ini menunjukkan bahwa pemanfaatan buah kemiri sudah berlangsung sejak tahun 1960-an hingga sekarang. Harga jual buah kemiri dari pemungut kepada pengepul sebesar Rp. 70.000,-/kg. Pemasaran kemiri sangat bagus dan didistribusikan ke seluruh pasar wilayah Situbondo dan sekitarnya.

Rambanan merupakan bagian dari pohon berupa ranting-ranting muda, pucuk daun, dan daun-daun yang dijadikan sebagai sumber pakan bagi ternak khususnya kambing Gambar 1. Aktifitas pemungutan rambanan ini sudah berlangsung sejak tahun 1970-an hingga sekarang, khususnya di Desa Sumberwaru. Mayoritas masyarakat yang memanfaatkan rambanan, yaitu yang memiliki ternak untuk dijadikan pakan dan jarang diperjualbelikan.

Pohon asam yang dimanfaatkan oleh masyarakat berupa buah (Gambar 1). Buah asam sudah dimanfaatkan oleh masyarakat penyangga TNB sejak tahun 1970an hingga sekarang. Harga rata-rata dari pemungut kepada pengepul sebesar Rp.6.000,-/kg. Pemasaran pengepul mencapai wilayah Kabupaten Jember, Lumajang, dan Probolinggo Jawa Timur. Metode pemungutan buah asam di TNB 
oleh masyarakat masih menggunakan kearifian lokal yaitu dengan memanjat dan menggunakan galah. Hal ini dilakukan masyarakat karena pernah kegagalan pada musim panen buah asam dikarenakan pemungutan dilakukan dengan memotong ranting dan cabang pohon yang terdapat banyak buah asamnya. Aktifitas ini menyebabkan banyaknya pucuk bunga yang menjadi bakal buah mati, sehingga musim berbunga di tahun berikutnya mengalami hambatan.

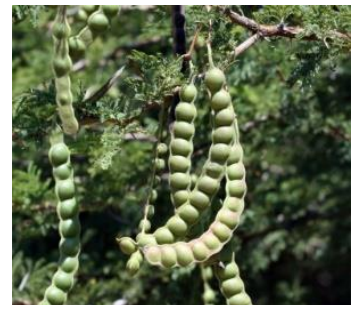

a. Buah akasia di pohon

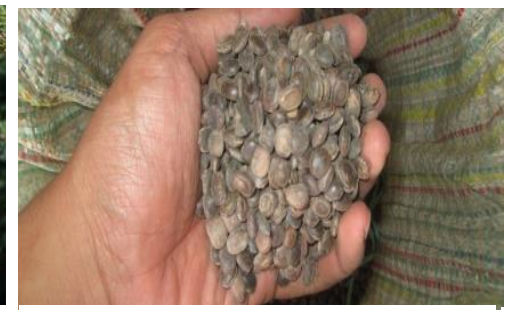

b. Biji akasia kering

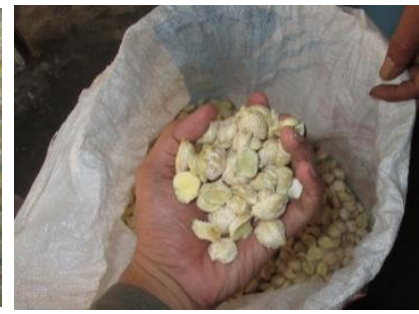

c. Biji kemiri

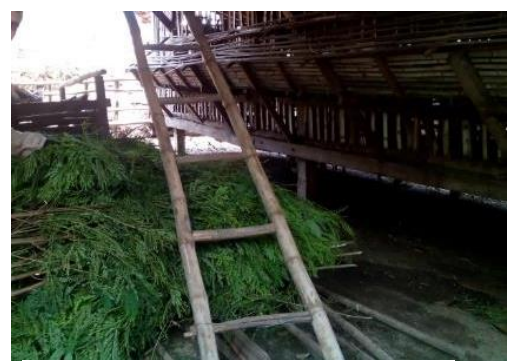

d. Ramban

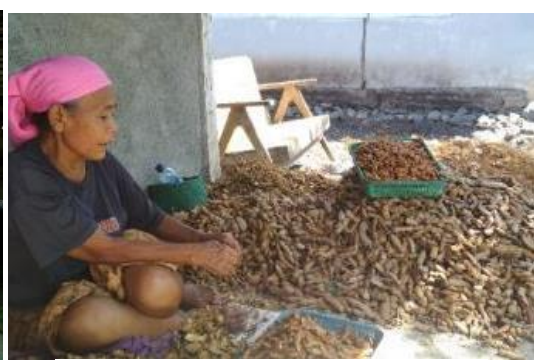

e. Pengeringan buah asam

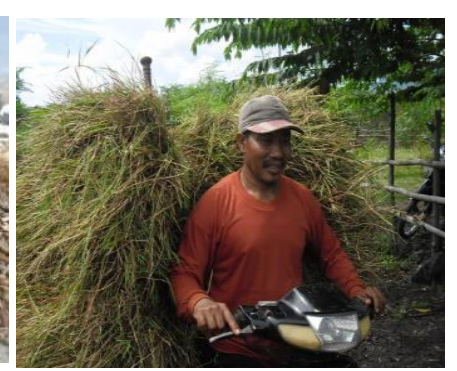

f. Pengankutan rumput

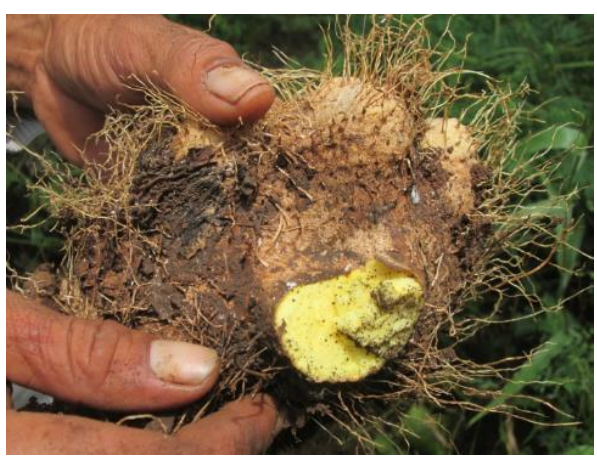

g. Gadung

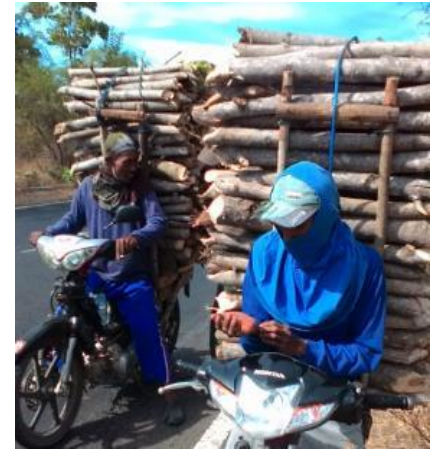

h. Pemungut kayu bakar TNB

Gambar 1. Pemanfaatan flora di TNB

Rumput merupakan jasa ekosistem TNB yang dimanfaatkan oleh masyarakat penyangga TNB sejak tahun 1960-an. Masyarakat mencari rumput di kawasan TNB untuk pakan hewan ternak sapi mereka dan ada juga yang mencari rumput untuk diperjual-belikan. Masyarakat sekitar TNB khususnya Desa Sumberwaru dan Desa Wonorejo hampir setiap hari masuk ke dalam kawasan TNB dan mengambil rumput (Gambar 1). Hal ini berbeda dengan Dewi et.al (2017) bahwa masyarakat sekitar 
TNB Desa Wonorejo memanfaatkan rumput sebanyak 4 kali dalam setahun, yaitu Bulan Januari smapai April. Hal ini diperkirakan berbeda waktu dan responden pada saat penelitian. Masyarakat mengambil rumput di wilayah zona inti dikarenakan potensi rumput yang disukai ternak sapi di wilayah tersebut sangat melimpah dibandingkan dengan di wilayah zona khusus dan zona tradisional.

Masyarakat memanfaatkan tanaman gadung yaitu berupa umbi (Gambar 1). Umbi gadung menjadi salah satu bahan pangan yang potensial untuk dikembangkan. Hasil penelitian ini ditemukan bahwa pemanfaatan gadung di TNB sudah berlangsung sejak tahun 1962 oleh masyarkat sekitar TN Baluran khususnya dari Desa Sumberanyar, Desa Sumberwaru, dan Desa Wonorejo. Pemasaran umbi gadung yang sudah siap untuk diolah selama ini masih memenuhi kebutuhan pasar di wilayah tapal kuda saja (Situbondo, Banyuwangi, Jember, dan Bondowoso). Harga jual umbi gadung dipasaran masih cukup tinggi. Harga jual umbi gadung basah dari pemungut kepada pengepul di TNB pada saat penelitian dilakukan sebesar Rp. 12.000,-/kg.

Jasa ekosistem berupa kayu bakar sudah dimanfaatkan oleh masyarakat desa penyangga TNB sejak tahun 1960-an awal, bahkan diperoleh informasi bahwa pemanfaatan kayu bakar TNB sudah dilakukan sejak status Baluran masih sebagai kawasan buru yang ditetapkan oleh Kolonial Belanda. Masyarakat di 5 desa penyangga TNB hingga saat ini mengambil dan mempergunakan kayu bakar tidak hanya untuk kebutuhan rumah tangga sendiri tetapi juga untuk diperjual belikan. Masyarakat pemungut kayu bakar setiap hari keluar masuk kawasan TNB melalui 12 pintu masuk kawasan TNB. Sebagian besar kayu bakar dipasarkan di wilayah tapal kuda (Situbondo, Banyuwangi, Jember, dan Bondowoso) dengan peruntukan sebagai bahan bakar di perusahaan batu bata, arang, dan di perusahaan tahu.

\section{Zonasi Pemanfaatan Flora}

Masing-masing jenis flora tersebut tersebar hampir di seluruh wilayah hutan TNB mulai dari zona pemanfaatan hingga zona inti taman nasional (Tabel 1). Jenis flora yang dimanfaatkan oleh masyarakat dipungut dari berbagai lokasi di wilayah hutan TNB tanpa memperhatikan status lokasi pengambilan tersebut dari segi peraturan zonasi taman nasional, padahal menurut Permenhut No. 56 Tahun 2006 tentang Pedoman Zonasi Taman Nasional, aktifitas pemanfaatan HHBK dan yang lainnya hanya diperbolehkan di 3 wilayah zona, yaitu di zona pemanfaatan, zona tradisional, dan di zona khusus.

Faktanya masyarakat tidak hanya mengambil SDAH di kedua zona tersebut tetapi juga di zona lainnya karena pengambilan yang dilakukan berdasarkan persebaran SDAH yang akan diambil (Tabel 3). Berdasarkan Tabel 3, lokasi 
pengambilan flora diambil dari zona inti sampai zona tradisional. Pengambilan sumber daya yang mencapai zona rimba bukan hanya karena persebaran sumber daya flora tersebut tetapi juga didukung dengan kemudahan akses.

Tabel 3. Jenis dan lokasi pemungutan HHBK berdasarkan zonasi TNB

\begin{tabular}{|c|c|c|c|c|c|c|c|c|c|}
\hline \multirow{2}{*}{ No } & \multirow{2}{*}{$\begin{array}{c}\text { Jenis HHBK yang } \\
\text { Dimanfaatkan }\end{array}$} & \multirow{2}{*}{$\begin{array}{c}\text { Blok } \\
\text { Pengambilan }\end{array}$} & \multicolumn{7}{|c|}{ Zona TNB } \\
\hline & & & $\mathbf{Z I}$ & $\mathbf{Z R}$ & ZKh & ZRh & $\mathbf{Z P}$ & ZT & $\mathbf{Z P b}$ \\
\hline \multirow[t]{14}{*}{1} & Akasia nilotika & Manting & & & & & $\sqrt{ }$ & & \\
\hline & & Balanan & & $\sqrt{ }$ & & & & & \\
\hline & & Merak & & $\sqrt{ }$ & & & & & \\
\hline & & Air karang & & $\sqrt{ }$ & & & & & \\
\hline & & Widuri & $\sqrt{ }$ & & & & & & \\
\hline & & Simacan & & $\sqrt{ }$ & & & & & \\
\hline & & Gunung motor & $\sqrt{ }$ & & & & & & \\
\hline & & Derbus & & & & $\sqrt{ }$ & & & \\
\hline & & Savana bekol & & & & $\sqrt{ }$ & & & \\
\hline & & Kajang & & & & & $\sqrt{ }$ & & \\
\hline & & Sirase & & $\sqrt{ }$ & & & & & \\
\hline & & Persil & & & & $\sqrt{ }$ & & & \\
\hline & & Gunung batok & & & & $\sqrt{ }$ & & & \\
\hline & & Gunung cabe & & & & $\sqrt{ }$ & & & \\
\hline \multirow[t]{4}{*}{2} & Kemiri & Sikesa & $\sqrt{ }$ & & & & & & \\
\hline & & Widuri & $\sqrt{ }$ & & & & & & \\
\hline & & Talpat & & $\sqrt{ }$ & & & & & \\
\hline & & Kacip & $\sqrt{ }$ & & & & & & \\
\hline \multirow[t]{7}{*}{3} & Rambanan & Paleran & & $\sqrt{ }$ & & & & & \\
\hline & & Licin & & $\sqrt{ }$ & & & & & \\
\hline & & Pengarengan & & $\sqrt{ }$ & & & & & \\
\hline & & Tekok abu & & $\sqrt{ }$ & & & & & \\
\hline & & Pemancar & & $\sqrt{ }$ & & & & & \\
\hline & & Amparan & & $\sqrt{ }$ & & & & & \\
\hline & & Watunumpuk & & & $\sqrt{ }$ & & & & \\
\hline \multirow[t]{5}{*}{4} & Asam & Tegal wero, & & & & & & $\sqrt{ }$ & \\
\hline & & Perengan & & $\sqrt{ }$ & & & & & \\
\hline & & Curah wedi & $\sqrt{ }$ & & & & & & \\
\hline & & Curah uling & $\sqrt{ }$ & & & & & & \\
\hline & & Curah udang & $\sqrt{ }$ & & & & & & \\
\hline \multirow[t]{6}{*}{5} & Rumput & Tegal wero & & & & & & $\sqrt{ }$ & \\
\hline & & Curah wedi & $\sqrt{ }$ & & & & & & \\
\hline & & Alas malang & $\sqrt{ }$ & & & & & & \\
\hline & & Air tawar & & & $\sqrt{ }$ & & & & \\
\hline & & Cangkring & $\sqrt{ }$ & & & & & & \\
\hline & & Duluk & $\sqrt{ }$ & & & & & & \\
\hline \multirow[t]{3}{*}{6} & Gadung & Talpat & $\sqrt{ }$ & & & & & & \\
\hline & & Kacip & $\sqrt{ }$ & & & & & & \\
\hline & & Gunung priuk & & $\sqrt{ }$ & & & & & \\
\hline
\end{tabular}




\begin{tabular}{|c|c|c|c|c|c|c|c|c|c|}
\hline \multirow{2}{*}{ No } & \multirow{2}{*}{$\begin{array}{c}\text { Jenis HHBK yang } \\
\text { Dimanfaatkan }\end{array}$} & \multirow{2}{*}{$\begin{array}{c}\text { Blok } \\
\text { Pengambilan }\end{array}$} & \multicolumn{7}{|c|}{ Zona TNB } \\
\hline & & & $\mathbf{Z I}$ & $\mathbf{Z R}$ & ZKh & ZRh & $\mathbf{Z P}$ & ZT & $\mathbf{Z P b}$ \\
\hline \multirow{8}{*}{7} & & Widuri & $\sqrt{ }$ & & & & & & \\
\hline & Kayu bakar & Bis & & $\sqrt{ }$ & & & $\sqrt{ }$ & & \\
\hline & & Unggahan bitakol & & $\sqrt{ }$ & & & & & \\
\hline & & Bilik & & & & & & $\sqrt{ }$ & \\
\hline & & Alas malang & & $\sqrt{ }$ & & & & & \\
\hline & & Pengarengan & & & & $\sqrt{ }$ & & & \\
\hline & & Bunutan & $\sqrt{ }$ & & & & & & \\
\hline & Jumlah & 47 & 16 & 17 & 2 & 6 & 3 & 3 & - \\
\hline
\end{tabular}

Keterangan : ZI (Zona Inti), ZR (Zona Rimba), ZKh (Zona Khusus), ZRh (Zona Rehabilitasi), ZP (Zona Pemanfaatan), ZT (Zona Tradisional), ZPb (Zona Perlindungan Bahari)

Pemanfaatan sumber daya yang dilakukan masyarakat di zona rimba pada dasarnya merupakan pengambilan sumberdaya secara ilegal karena bertentangan dengan Permenhut No. 56 Tahun 2006 dan Surat Keputusan Direktur Jenderal Perlindungan Hutan dan Konservasi Alam nomor 228/IV-SET/2012 Tentang Zonasi Taman Nasional Baluran yang menyebutkan bahwa di dalam zona inti tidak boleh dilakukan pengambilan hasil hutan. Zona rimba berdasarkan Permenhut tersebut diperuntukkan untuk kegiatan pengawetan dan pemanfaatan sumberdaya alam dan lingkungan alam bagi kepentingan penelitian, pendidikan konservasi, wisata terbatas, habitat satwa migran dan menunjang budidaya serta mendukung zona inti.

Pengambilan sumber daya flora yang mencapai zona rimba dikhawatirkan dapat mengganggu fungsi dari zona rimba sebagai penyangga perlindungan ekosistem dan pengawetan sumberdaya alam di zona inti terlebih lagi jika pengambilan yang dilakukan memiliki interaksi yang tinggi. Interaksi antara masyarakat dengan kawasan TNB terjadi sepanjang tahun dengan jenis sumber daya alam hayati yang berbeda-beda. Saat musim pengambilan suatu jenis sumber daya tiba, maka bagian dari kawasan TNB tersebut akan sering didatangi oleh masyarakat. Tinggi dan rendahnya interaksi yang terjadi ditentukan oleh banyaknya jenis sumber daya yang diambil dan intensitas pengambilan tiap sumber daya selama satu tahun. Interaksi yang terjadi antara masyarakat desa penyangga paling tinggi dalam pemanfaatan flora yaitu di zona rimba. Hal ini yang harus menjadikan perhatian TNB untuk mengantisipasi dan mengendalikan kerusakan yang mungkin terjadi akibat interaksi tersebut serta mengajak masyarakat lebih paham fungsi setiap zona dan pemanfaatan sumber daya secara bijaksana. 


\section{SIMPULAN}

Jenis flora yang dimanfaatkan oleh masyarakat desa penyangga berjumlah 7 jenis dengan nilai ekonomi sebesar Rp. 14.110.295.400 dengan kontribusi terhadap perekonomian masyarakat mayoritas tinggi. Nilai ekonomi flora yang dimanfaatkan masyarakat ini menunjukkan bahwa TNB telah memberikan kontribusi dan manfaat terhadap peningkatan kesejateraan masyarakat desa penyangga melalui pemanfaatan flora di dalam kawasan. Akan tetapi pemanfaatan yang dilakukan masih didominasi pemanfaatan yang dapat dikatakan illegal karena mayoritas terjadi di zona rimba.

\section{DAFTAR PUSTAKA}

[Balai TNB] Balai Taman Nasional Baluran. (2014). Identifikasi dan Pemetaan Sebaran HHBK dan Pemanfaatannya oleh Masyarakat di Taman Nasional Baluran. Situbondo: Balai TNB.

Dewi, E.C., Sunarminto T, Arief H. (2017). Nilai Ekonomi Pemanfaatan Sumberdaya Alam Hayati Taman Nasional Baluran oleh Masyarakat Desa Wonorejo Kabupaten Situbondo Jawa Timur. Media Konservasi, 22(3), 277283.

[Dephut] Departemen Kehutanan. (2006). Peraturan Menteri Kehutanan Nomor 56 Tahun 2006 Tentang Pedoman Zonasi Taman Nasional. Jakarta: Departemen Kehutanan.

Ekayani, M., Nuva, Yasmin R., Sinaga F., Maaruf LOM. (2014). Wisata alam Taman Nasional Gunung Halimun Salak: solusi kepentingan ekologi dan ekonomi. Jurnal Ilmu Pertanian Indonesia, 19(1), 29-37.

Fauzi, A. (2016). Valuasi Ekonomi Dan Penilaian Kerusakan Sumber Daya Alam Dan Lingkungan. Bogor: IPB Press.

Munanura, I.E, Kenneth F.B, DeWayne D.M, Jeffrey CH, Robert BP. (2014). Household poverty dimensions influencing forest dependence at Volcanoes National Park, Rwanda: An application of the sustainable livelihoods framework. J Natur Resour, 5, 1031-1047.

Nugroho, B.T.A, Ni Kadek EU, Mustaid S. (2008). Interaksi masyarakat sekitar hutan terhadap pemanfaatan keanekaragaman hayati di Kawasan Ekosistem Hutan Alami Bedugul-Pancasari, Bali. J Biodivers, 9 (3), 227-231.

Permenhut No. 56 Tahun 2006 dan Surat Keputusan Direktur Jenderal Perlindungan Hutan dan Konservasi Alam nomor 228/IV-SET/2012 Tentang Zonasi Taman Nasional Baluran.

Soekmadi, R. (2003). Pergeseran paradigma pengelolaan kawasan konservasi: sebuah wacana baru dalam pengelolaan kawasan konservasi. Media Konservasi, 8(3), 87-93. 
Wanamukti Vol.23, No. 2 Oktober 2020:64-75

DOI: http://dx.doi.org/10.35138/wanamukti.v23iI1.220
p-ISSN: $1412-8381$

e-ISSN: 2621-833X

Sugiyono. 2009. Metode Penelitian Kuantitatif Kualitatif dan RD. Bandung: Alfabeta.

Suhendang Endang. 2013. Pengantar Ilmu Kehutanan. Bogor: IPB Press. 